\title{
DID ULYSSES TRAVEL TO ATLANTIS?
}

Rainer W. Kühne

Tuckermannstr. 35, 38118 Braunschweig, Germany

kuehne70@gmx.de

Good fiction imitates facts. Plato declared that his Atlantis tale is philosophical fiction invented to describe his fictitious ideal state in the case of war. I suggest that Plato used three historical elements for this tale. (i) Greek tradition on Mycenaean Athens for the description of ancient Athens, (ii) Egyptian records on the wars of the Sea Peoples for the description of the war of the Atlanteans, and (iii) oral tradition from Syracuse about Tartessos for the description of the city and geography of Atlantis.

\section{Odyssey}

Homer's Odyssey is poetry. It is often regarded as pure fiction. This view is supported by Ulysses' adventures with giants like the Cyclops, goddesses like Athena and Circe, nymphs like Calypso, beasts like Scylla, and demons like the sirens.

On the other hand, Schliemann interpreted Scylla and Charybdis as the Strait of Messina. He interpreted Ogygia, the island of Calypso, as the east coast of Sicily, and Sheria, the country of the Phaeaceans, as Corfu [1].

Various authors have pointed out the similarities between Homer's Sheria and Plato's Atlantis $[2,3]$. However, these similarities are not very specific.

(1) The capitals of both Sheria (Od. 5.401) and Atlantis (Crit. 118a) lay near a steep coast.

(2) The capital of Sheria was surrounded by a high wall (Od. 6.262). The capital of Atlantis was surrounded by several walls (Crit. 116a).

(3) There were two harbours which allowed only a narrow entrance to the capital of Sheria (Od. 6.263-264). The capital of Atlantis was surrounded by three harbours (Crit. 117d).

(4) In the harbours of both Sheria (Od. 6.264-265) and Atlantis (Crit. 116b) there were many ships.

(5) In the capital of Sheria there was a realm of Poseidon (Od. 6.266) and the palace consisted of gold, silver, copper and electron (Od. 7.82-91). In the capital of Atlantis there was a grove of Poseidon (Crit. 117b) and the temple of Poseidon consisted of gold, silver, ivory and orichalcum (Crit. 116d).

(6) In Sheria one could harvest fruit twice a year (Od. 7.117-119). In Atlantis one could harvest twice a year (Crit. 118a).

(7) In Sheria there were two springs (Od. 7.129) and warm baths (Od. 8.249). In Atlantis there were two springs, one cold and one hot (Crit. 113e, 117a), and warm baths (Crit. $117 b)$.

(8) In Sheria reigned 13 kings simultaneously (Od. 8.390), who were descendants of Poseidon (Od. 13.130). In Atlantis reigned 10 kings simultaneously (Crit. 113e-114a, $116 \mathrm{e}, 119 \mathrm{c}$ ), who were descendants of Poseidon (Crit. 113e-114c).

(9) Both the kings of Sheria (Od. 8.431) and Atlantis (Crit. 120a) used gold goblets for drinking during ceremonies.

\section{Fictional Elements}


Plato's Atlantis tale (Timaios 20d-27a, Critias 106a-121c) is philosophical fiction invented to describe Plato's fictitious ideal state in the case of war (Tim. 19b-20c). Plato invented the Atlantis tale after he failed twice in educating the tyrants of Syracuse to behave like philosopher kings $[4,5]$. The Atlantis tale includes several elements which are based on neither Egyptian nor Greek historical records, but result from Plato's philosophical views:

(1) The Phaethon myth has an astronomical explanation (Tim. 22c-d).

(2) Several floods (Tim. 23b) and cataclysms (Tim. 22c, 23a-b) have occured during human history.

(3) The Greek city of Athens is older than the Egyptian city of Sais (Tim. 23e).

(4) The ancient Athens was reigned like Plato's ideal state (Tim. 24a-b, 25e).

(5) The ancient Athens has won a world war (Tim. 24e, 25c, Crit. 108e).

(6) A continent exists beyond the Atlantic Sea (Tim. 25a).

(7) The war was a joint venture of the Hellenes (Tim. 25b-c) which occured long before the happenings of the Greek myths (Tim. 22a-c). By contrast, the first joint venture of the Hellenes was the Trojan war (Thucydides 1,3).

(8) There is a mud sea in front of the Strait of Gibraltar (Tim. 25d, Crit. 108e-109a).

(9) The then acropolis of Athens was very large (Crit. 112a). By contrast, Thucydides noted that all castles of the Mycenaean time appear small for his contemporaries $(1,10)$.

(10) The Atlanteans had triremes (Crit. 117d). By contrast, the first triremes were used by the Corintheans in the 8th century BC (Thucydides 1,13 ).

\section{Ancient Athens}

Plato's description of the ancient Athens resembles the Bronze Age Athens during the period Late Helladic IIIB around 1200 BC. This suggests that Plato has used either Greek tradition or own investigations for the description of ancient Athens. These similarities include the following claims:

(1) The accomodations of the warriors were in the northern part of the Athenian acropolis (Crit. 112b). In fact, this was the location of their accomodations from the 15 th century until around $1200 \mathrm{BC}[6]$.

(2) A spring on the Athenian acropolis has been destroyed by earthquakes just after the war against the Atlanteans (Crit. 112c-d). In fact, Broneer excavated this fountain which has existed for only 25 years and has been destroyed by an earthquake around $1200 \mathrm{BC}[7]$. 
(3) The Greeks had knowledge of writing until this earthquake (Tim. 23c). Indeed, the Mycenaean Linear B was written in Greek language [8] and its knowledge became lost in Greece around 1200 BC.

\section{Sea Peoples}

Around $1200 \mathrm{BC}$ the countries in Asia Minor and the Near East were destroyed by a war [9]. The attackers were the Sea Peoples described by Pharaoh Ramses III [10]. The similarities between the Sea Peoples and the Atlanteans [11-13] suggest that Plato has used Egyptian records for the description of the Atlantean war. Quotations of the temple inscriptions are given in the combination of plate number and line number:

(1) The Atlanteans fought against Europe and Asia (Tim. 24e) and "every country within the mouth", i. e. against the Eastern Mediterranean countries (Tim. 25b). The Sea Peoples destroyed Hatti in Anatolia, Qode and Qarkemish in northern Syria, Arzawa in southwest Anatolia, and Alasia on Cyprus (Plate 46.16 - 17) and fought against Egypt.

(2) The Atlanteans lived on an isle (Tim. 24e, 25a, 25d, Crit. 113c) and reigned over several other islands (Tim. 25a). Also the Sea Peoples came from islands (Pl. 37.8 - 9, $42.3,46.16)$.

(3) The Atlanteans reigned in Africa from the pillars of Heracles (Gibraltar) to the frontiers of Egypt (Tim. 25a - b). The war of the Sea Peoples against Egypt occured simultaneously with the war of the Libyan Meshwesh. According to Ramses' report they appeared to be allied.

(4) Atlantis consisted of ten countries (Crit. 113e-114a, 119b). According to the Karnak inscription written under pharaoh Merenptah around 1200 BC, the Sea Peoples consisted of the Ekwesh, Teresh, Lukka, Sherden, and Shekelesh. According to Ramses III their confederation consisted of the union of the countries of the Peleset, Theker, Shekelesh, Denen, and Weshesh (Pl. 46).

(5) In the case of war the Atlanteans had more than one million soldiers (Crit. 119a -

b). Ramses III claimed to have beaten hundreds of thousands of enemies (Pl. 18.16, 19.4 - 5, 27.63, 32.10, 79.7, 80.36, 80.44, 101.21, 121c.7). Occationally, he spoke of millions (Pl. 27.64, 46.4, 46.6, 79.7, 101.21) and myriads (P1. 27.64) of enemies who were numerous like locusts (P1. 18.16, 80.36) or grasshoppers (P1. 27.63).

(6) The Atlanteans had 1200 war ships (Crit. 119b). The ships of the Sea Peoples entered deep into the delta of the Nile (Pl. 42.5) and destroyed the Asian Arzawa, the Cypric Alasia, and the near-eastern Ugarit and Amurru.

(7) The Atlanteans had chariots pulled by horses (Crit. 119a). The Meshwesh had horses (Pl. 75.37) and carts (Pl. 18.16, 75.27) which, however, were pulled by oxes (figures to Pl. 32 - 34). 
(8) The Atlantean kings reigned for several generations (Crit. 120d - e) and after this they lost their good attitudes (Crit. 121a - b). Ramses III wrote about the Sea Peoples that they had spent a long time, a short moment was before them, then they entered the evil period (Pl. 80.16 - 17).

(9) During a day and a night Atlantis sank by a earthquake into the sea (Tim. 25c - d). Ramses III wrote that he let the Sea Peoples see the majesty and force of (the God of water) Nun when he breaks out and lays their towns and villages under a surge of water (Pl. 102.21), moreover the mountains were in travail (Pl. 19.11).

\section{Tartessos}

Plato described the place of the Atlantean capital. The capital (Crit. 115c) was on a to-allsides flat hill which was 50 stades (9 kilometres) distant from the sea and lay at the edge of a plain (Crit. 113c). This plain was rectangular (Crit. 118c), smooth and even. The plain lay on the southern part of the isle (Crit. 118a-b), in its middle (Crit. 113c). The plain was surrounded by mountains which reached to the sea (Crit. 118a). Apart from this, the country was very high and had a steep coast (Crit. 118a).

The isle of Atlantis was divided under the ten sons of Poseidon (Crit. 113e). The first born, Atlas, obtained the largest and best territory, namely the region around the capital (Crit. 114a). The second born, Gadeiros, obtained the part at the most distant edge which reached from the pillars of Heracles (Gibraltar) to the Gadeirean country (the region around Cadiz) (Crit. 114b).

The first born, Atlas, obtained the largest and best part. Therefore one can assume that the later born sons obtained smaller and smaller parts. According to this, the second born son, Gadeiros, obtained the second largest part of the "isle of Atlantis". This part included the coastal region of Spain from Cadiz to Gibraltar. Here, the term "isle" should be rather understood as "coast" or "region".

The part of the country belonging to Gadeiros was only a coastal region 100 kilometres long. The parts of the later born sons were probably even smaller. Thus, the part of the country belonging to Atlas cannot have been very far from Cadiz.

In fact, near Cadiz there is a rectangular (Crit. 118c), smooth and even plain which lies at a south coast (Crit. 118a-b). It is the plain south-west of Seville through which the Guadalquivir flows. Was here the capital of Atlantis?

The geography of Atlantis resembles that of the Iron Age Tartessos [13-18]. This suggests that Plato has heard about Tartessos from Greek sailors during his visits in Syracuse. There are the following similarities between Tartessos and Atlantis:

(1) Tartessos lay in the mouth of the Guadalquivir river. Atlantis lay in front of the pillars of Heracles, i. e. Gibraltar (Tim. 24e, Crit. 108e) and at a south coast (Crit. $118 b)$.

(2) The plain of Tartessos included a system of channels. Plato reported the same about the plain of Atlantis (Crit. 118d-e). 
(3) Tartessos was surrounded by the Sierra Morena and the Sierra Nevada. The plain of Atlantis was surrounded by high mountains (Crit. 118a-b).

(4) Tartessos was rich in metals. Plato reported the same about Atlantis (Crit. 114e).

(5) According to archaeological evidence and Strabon (III 139), the Tartessians had knowledge of writing. Plato wrote the same about the Atlanteans (Crit. 119c-d).

\section{Conclusion}

Plato's Atlantis tale (Timaios 20d-27a, Critias 106a-121c) is philosophical fiction invented to describe Plato's fictitious ideal state in the case of war (Tim. 19b-20c). Plato invented the Atlantis tale after he failed twice in educating the tyrants of Syracuse to behave like philosopher kings [1,2]. However, the Atlantis tale appears to include three historical elements [10].

(1) Plato's description of ancient Athens resembles Mycenaean Athens of the period LH IIIB around $1200 \mathrm{BC}[3,4]$. Plato appears to have used either Greek tradition or own investigations.

(2) Plato's description of the Atlantean war resembles the war of the Sea Peoples around $1200 \mathrm{BC}$ [8-10]. Plato appears to have used the temple inscriptions of Medinet Habu written under pharaoh Ramses III.

(3) Plato's description of the city and geography of Atlantis resembles that of iron age Tartessos [10-15]. Plato appears to have heard about Tartessos during his visits in Syracuse.

\section{Outlook}

Preliminary evidence for Atlantis in the Guadalquivir valley has been presented by Werner Wickboldt at the conference "The Atlantis Hypothesis: Searching for a Lost Land", 11-13 July 2005, Milos Island, Greece. He presented a satellite photo of the Donana National Park which showed the following structures.

(1) A rectangular structure of size 230 metres times 140 metres which could be a remnant of the "silver temple of Poseidon" (Crit. 116c-d). The geographical coordinates of this structure are $36^{\circ} 57^{\prime} 25^{\prime \prime}+/-6^{\prime \prime} \mathrm{N}$ and $6^{\circ} 22^{\prime} 58^{\prime \prime}+/-8^{\prime \prime} \mathrm{W}$.

(2) A rectangular structure of size 280 metres times 240 metres located 500 metres southwest of the first structure. It could be a remnant of the "golden temple of Poseidon and Cleito" (Crit. 116c).

(3) These two structures are surrounded by parts of concentric rings. They could be remnants of the concentric rings of earth and water (Crit. 115e-116a).

(4) A chain of lakes located north-west of these structures which could be a remnant of the channel which ranged from the capital of Atlantis to the sea (Crit. 115d).

\section{Literature}


1. H. Schliemann, Ithaka, der Peloponnes und Troja (Leipzig, Giesecke \& Devrient, 1869).

2. F. Kluge, De Platonis Critia, Rheinisches Museum für Philologie 75 (1910) 283.

3. W. Leaf, Homer and History (London, Macmillan, 1915).

4. E.S. Ramage (ed.), Atlantis - Fact or Fiction? (Indiana University Press 1978).

5. P.Y. Forsyth, Atlantis - The Making of Myth (McGill - Queen's University Press 1980).

6. O. Broneer, What Happened at Athens, American Journal of Archaeology 52 (1948) 111 124.

7. O. Broneer, A Mycenaean Fountain on the Athenian Acropolis, Hesperia 8 (1939) 317 429.

8. M. Ventris and J. Chadwick, Evidence for Greek Dialect in the Mycenaean Archives, Journal of Hellenic Studies 73 (1953) 86 - 103.

9. R. Drews, The End of the Bronze Age (Princeton University Press 1993).

10. W.F. Edgerton and J.A. Wilson, Historical Records of Ramses III (University of Chicago Press 1936).

11. S. Marinatos, Peri ton Thrulon tes Atlantidos, Kretica Chronika 4 (1950) 195 - 213.

12. H. Görgemanns, Wahrheit und Fiktion in Platons Atlantis-Erzählung, Hermes 128 (2000) $405-419$.

13. R.W. Kühne, A Location for Atlantis?, Antiquity 78, 300 (2004);

http://antiquity.ac.uk/ProjGall/kuhne .

14. O. Jessen, Tartessos-Atlantis, Zeitschrift der Gesellschaft für Erdkunde (1925) 184.

15. R. Hennig, Das Rätsel der Atlantis, Meereskunde 14 (1925) 1 - 29.

16. R. Hennig, Zum Verständnis des Begriffs "Säulen" in der antiken Geographie, Petermanns geographische Mitteilungen 73 (1927) 80 - 87.

17. A. Schulten, Tartessos und Atlantis, Petermanns geographische Mitteilungen 73 (1927) $284-288$.

18. A. Schulten, Atlantis, Rheinisches Museum für Philologie 88 (1939) 326 - 346.

Dr. Rainer W. Kühne

Tuckermannstr. 35

38118 Braunschweig

Germany

e-mail: kuehne70@gmx.de

phone: +49(0)5312506442 
